U. S. Atomic Energy Commission

Chicago Operations Office

9800 South Cass Avenue

Argonne, Illinois

Attention: Mr. Steven V. White, Director

Research Contracts Division
This document is

PUBLICLY RELEASABLE

3 ang stede

Authorizing Official

Date: $2 \cdot 20-07$

Subject: Contract No。AT(11-1)-742

Gentlemen:

This informal letter report is the fourth of a series of monthly letter reports for the contract year, 1 May 1960 to 30 April 1961, describing progress made on the research program, "Study of Factors Influencing Ductility of Iron-Aluminum Alloys," Contract No。AT(1l-1)-742.

The objective of the program is to determine the effect of variations of aluminum content, heat treatment, surface preparation and other metallurgical. factors upon the room-temperatures ductility of $\mathrm{Fe}-\mathrm{Al}$ alloys. Since alloys containing in excess of $10 \%$ aluminum are characterized by order-disorder transformations, heat treatment will provide the means for evaluating the effect of disorder and varying degrees of order upon the mechanical properties of these alloys. With a quantitative knowledge of these effects it may then be possible to improve the room temperature ductilities of $\mathrm{Fe}-\mathrm{Al}$ alloys by suitable control of processing variables.

It is estimated that $25 \%$ of the proposed research has been completed during the first four months of the contract period.

\title{
Resistivity Measurements
}

Curves of resistivity vs. time for isothermally annealed alloys which had previously been ordered $\left(\mathrm{Fe}_{3} \mathrm{Al}\right)$ have been reported for the $13.6-$ and 13.90 Alfenol compositions. These studies have been continued on 35 mil thick 16 o Alfenol during this report period, The results, summarized in Figure 1 , are comparable to those obtained on the 13.6-and 13.9-Alfenols. 


\section{DISCLAIMER}

This report was prepared as an account of work sponsored by an agency of the United States Government. Neither the United States Government nor any agency Thereof, nor any of their employees, makes any warranty, express or implied, or assumes any legal liability or responsibility for the accuracy, completeness, or usefulness of any information, apparatus, product, or process disclosed, or represents that its use would not infringe privately owned rights. Reference herein to any specific commercial product, process, or service by trade name, trademark, manufacturer, or otherwise does not necessarily constitute or imply its endorsement, recommendation, or favoring by the United States Government or any agency thereof. The views and opinions of authors expressed herein do not necessarily state or reflect those of the United States Government or any agency thereof. 


\section{DISCLAIMER}

Portions of this document may be illegible in electronic image products. Images are produced from the best available original document. 
Tensile Property Studies

Studies designed to correlate tensile properties with varying degrees of long $r$ ange order were initiated on 13.9 Alfenol during the past month. The isothermal resistivity vs. time curves for a recrystallized alloy of this composition were used as a basis for scheduling heat treatment of specimens. An SR-4 strain gage, type A-7, was mounted on one surface of each specimen for the purpose of obtaining the respective stress-strain curves. A $0.1 \%$ offset was used for determining yield strengths。

Figure II summarizes the results obtained on four specimens. Curve (a) is the stress-strain relationship for a specimen of nearly perfect $\mathrm{Fe}_{3} \mathrm{Al}$ order, and curve (d) is that for nearly complete $\mathrm{Fe}_{3} \mathrm{Al}$ disorder. Curves (b) and (c) were obtained from specimens of intermediate degrees of order, (b) being more highly ordered than (c). It will be noted that as the degree of order decreases, Young's Modulus of Elasticity steadily decreases. Yield strength, however。 fluxuates radically with decreasing order. Interpretation of these results must await further experimentation.

\section{Future Considerations}

The fabrication of $13.9,16$ - Alfenol and Thermenol is now in the final. stages of completion. The tunnel furnace, which was constructed to minimize the possibility of micro cracking during fabrication, is being employed in the warm-rolling procedure.

Other studies will include isothermal resistivity measurements on Thermenol, continuation of tensile property studies employing SR-4 strain gages on 13.9- and 16-Alfenol, and development of X-ray diffraction technique for quantitative measurements of degree of long $r$ ange atomic order.

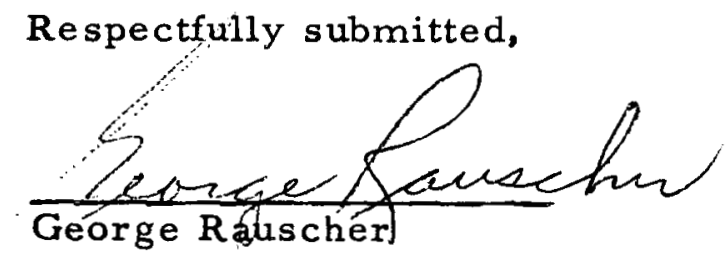

Graduate Research Assistant

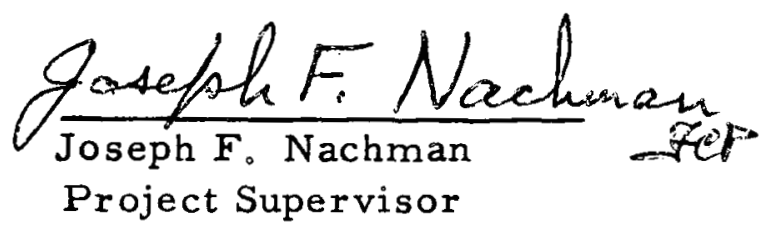




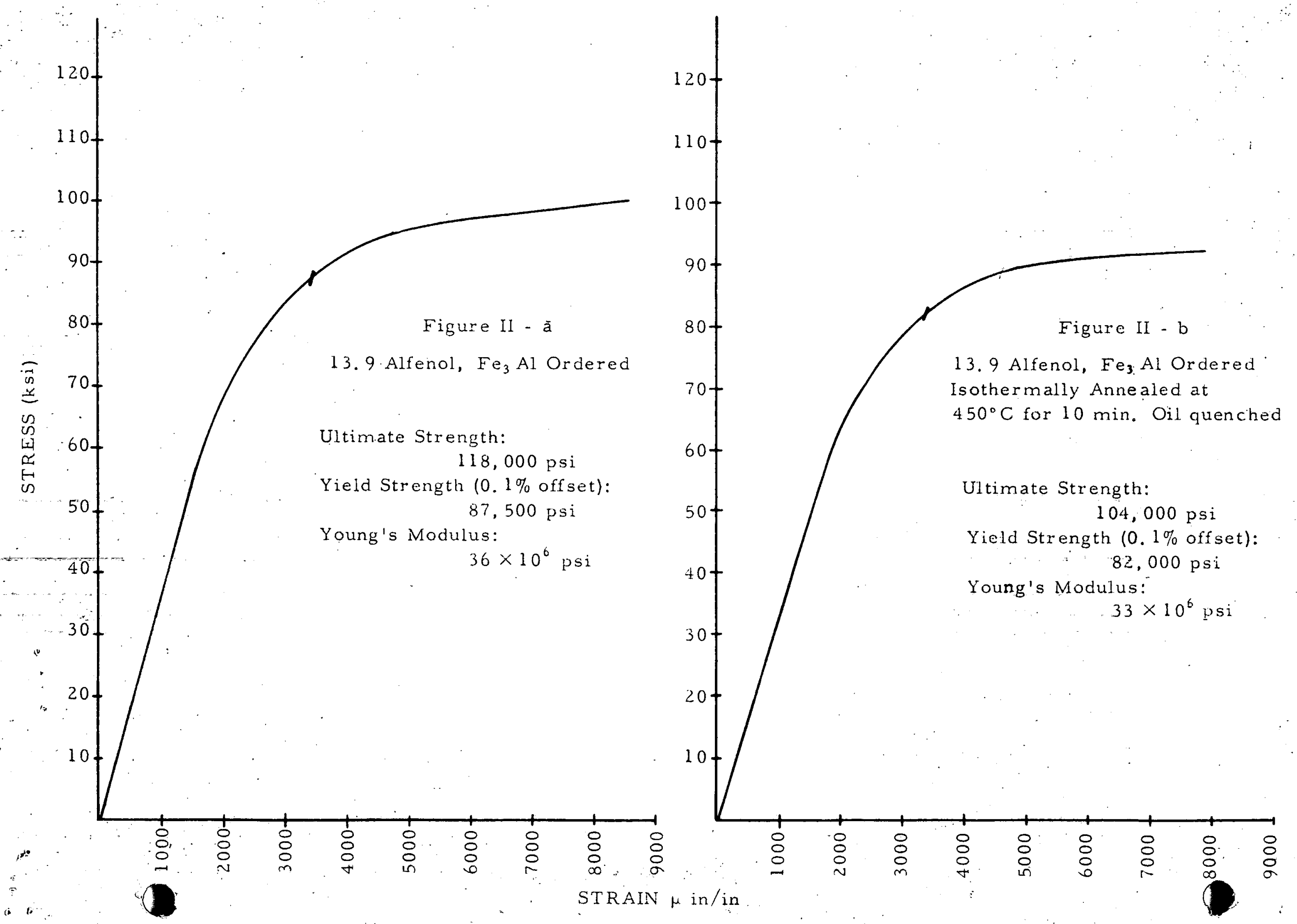



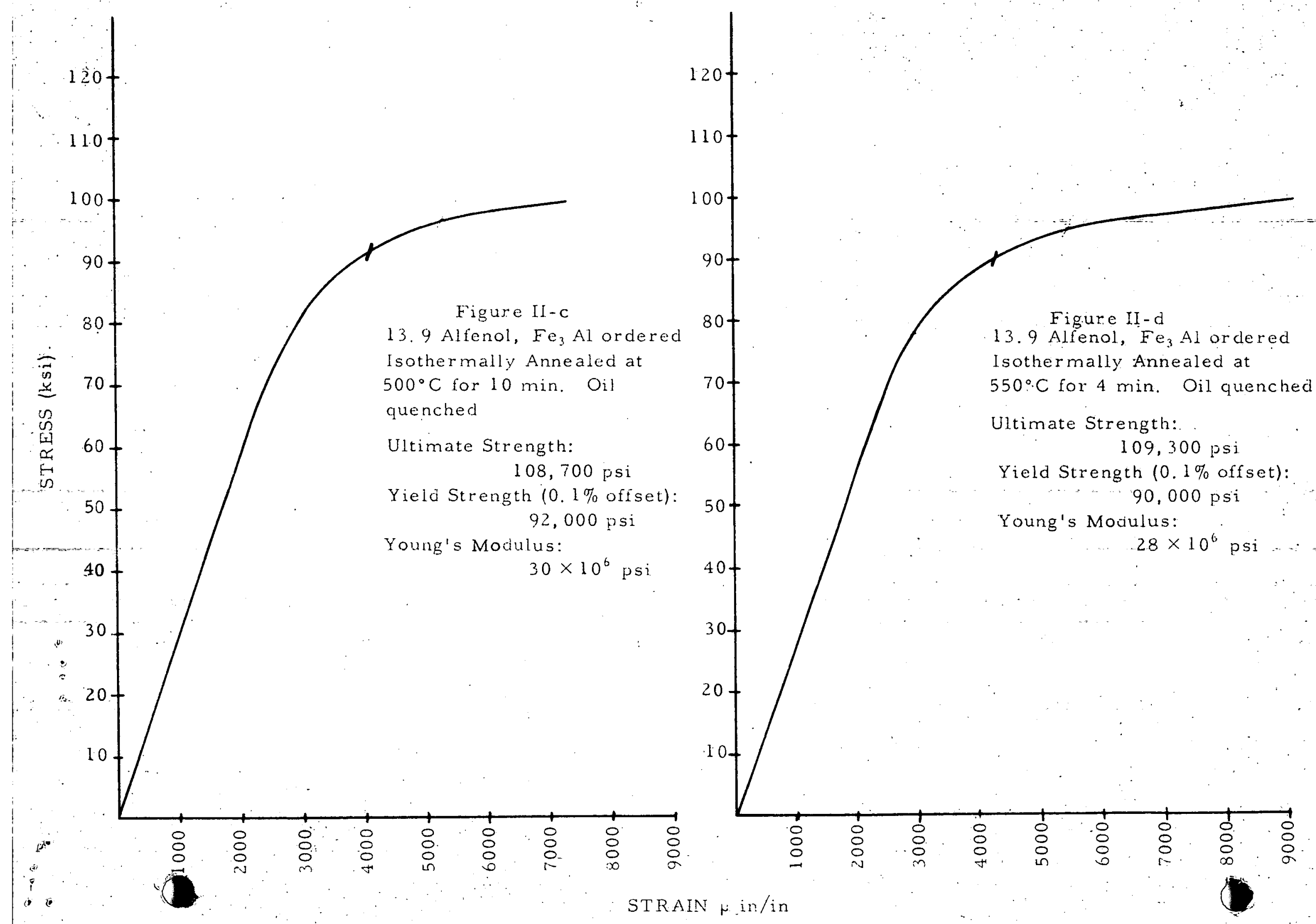